\title{
Blood Flow Rate
}

National Cancer Institute

\section{Source}

National Cancer Institute. Blood Flow Rate. NCI Thesaurus. Code C94866.

The volume of blood per unit time passing through a specified location, such as a point in a blood vessel or an entire organ. Units are $\mathrm{ml} / \mathrm{sec}$. 